\title{
A mentorship model for teacher education: Young STEM researchers and practitioners program
}

\author{
Defne Yabaş \\ Bahçesehir University, İstanbul, Turkey, defneyabas@gmail.com \\ Hayriye Sinem Bozoğlu iD \\ Darussafaka schools, İstanbul, Turkey, hayriye.boyaci123@gmail.com
}

ABSTRACT The current research is about the impact of the young STEM researchers and practitioners program implemented within the STEM: Integrated teaching project. The aim of the program is to incorporate STEM integrated teaching knowledge in the teacher preparation period. In this phenomenological study, we explored five pre-school teachers' program experiences and their STEM conceptions. Data were collected with semi-structured interviews, including questions about the impact and elements of the program and participants' STEM conceptions. Content analysis showed that awareness for STEM education, development of integrated teaching knowledge, and program elements were the emergent themes about the program experience. Teacher candidates responded to the models that include realworld problems and engineering as contexts as most desirable when shown STEM education models to understand their STEM conceptions. The young STEM researchers and practitioners program can be evaluated as a developing model to be incorporated into teacher education programs. Further research can explore how pre-service teachers form their STEM conceptions and develop their integrated teaching knowledge.

Keywords: $\quad$ Early STEM, Integrated teaching knowledge, STEM education, Teacher education

\section{Öğretmen yetiştirmede bir mentörlük modeli: Genç STEM araştırmacıları ve uygulamacıları programı}

ÖZ Bu çalışmada STEM: Bütünleşik Öğretmenlik Çerçevesi kapsamında uygulanan "Genç STEM Araştırmacıları ve Uygulayıcıları Programının" etkisi programdan mezun olan katılımcıların görüşleri aracılığıyla incelenmiştir. Genç STEM Araştırmacıları ve Uygulamacıları Programının temel amacı, STEM bütünleșik öğretmenlik bilgisini öğretmen yetiștirme sürecine dahil etmektir. Yapılan fenomenolojik çalışmada, okul öncesi öğretmenlerinden program deneyimleri ve STEM eğitimi algıları ile ilgili veri toplanmıştır. Veriler, programın etkisi ve program bileşenleri ile katılımcıların STEM algıları hakkındaki soruları içeren bir görüşme protokolü ile toplanmıştır. Verilerin içerik analiziyle çözümlenmesi sonucunda, öğretmenlerin STEM eğitimine yönelik farkındalıklarının artması, bütünleşik öğretmenlik bilgisinin geliştirilmesi, program bileşenleri ve program deneyimi kategorileri ortaya çıkmıştır. Katılımcıların STEM algılarını incelemek için kullanılan STEM eğitimi modelleri gösterildiğinde, öğretmenler gerçek yaşam problemlerini ve mühendislik tasarım sürecini içeren modelleri tercih etmişlerdir. Genç STEM araştırmacıları ve uygulayıcıları programı, öğretmen yetiştirme programları için gelişmekte olan bir model olarak değerlendirilebilir. Gelecek araştırmalar, öğretmen adaylarının STEM kavramlarını nasıl oluşturduklarını ve bütünleşik öğretmenlik bilgilerini nasıl geliştirdiklerini keşfetmeye odaklanabilir.

Anahtar

Sözcükler: Bütünleşik öğretmenlik bilgisi, Erken STEM, Ö̆gretmen yetiştirme, STEM eğitimi

\footnotetext{
Citation: $\quad$ and practitioners program. Turkish Journal of Education, 11(1), 36-55.

https://doi.org/10.19128/turje.950335
} 


\section{INTRODUCTION}

In the 21st century, individuals have increasing expectations to have skills and knowledge in science, technology, engineering, and mathematics. 21st-century citizens are exposed to complicated, multidisciplinary, and multi-dimensional problems such as energy, resources, and pandemics. In this sense, STEM education at the K-12 level provides a set of skills within rigorous science, technology, engineering, and mathematics teaching-learning activities for every student. Hence, "STEM education includes the knowledge, skills, and beliefs that are collaboratively constructed at the intersection of more than one STEM subject area" (Corlu, 2017; Corlu et al., 2014).

The importance of STEM education has been underlined in educational policy documents, based on the need for competent individuals equipped with complex problem solving and scientific inquiry skills. STEM education aligns with contemporary education outcomes with its potential for providing guidelines for innovative education programs (Bybee, 2013), and raising a generation with innovative mindsets (Corlu, 2012). In different countries' policy documents, the focus of STEM education includes a student-centered approach facilitated by teachers to establish rigorous learning environments (National Research Council [NRC], 2011). The educational vision document published by the Turkish Ministry of National Education (MoNE) also emphasizes the need to provide quality learning experiences within STEM education (MoNE, 2019).

Although STEM education's potential is widely acknowledged, establishing a learner and learning centered approach is needed to develop relevant skills. Embracing a pedagogical approach in STEM education underlines interdisciplinary contexts based on authentic problems of the knowledge society and taught with integrated content and methodologies (Aşık et al., 2017). The acronym STEM gives little clue about the nature of the curriculum, instructional approaches, and assessment practices in the learning environments (Bybee, 2013). The word STEM has been used within many different perspectives leading to many different conceptions and interpretations of educators (Dare et al., 2019). From this perspective, the need for establishing fundamental qualities of STEM education using a coexisting language is a necessity.

To establish a pedagogical understanding about STEM education, the content and the quality of preservice teacher preparation programs come forth. Studies showed that teachers who graduated from integrated teaching programs feel more confident and have more positive attitudes than their colleagues who graduated from departmentalized programs (Corlu, 2012). Through balanced coursework of content, pedagogy, and pedagogical content knowledge, teacher candidates found more opportunities to develop their integrated teaching knowledge and parallel teaching practices (Corlu, 2012; Sanders, 2009). Integrated teaching knowledge makes teachers responsible for teaching their subjects and guiding their students in at least one other STEM subject (Sanders, 2009). Teachers with integrated knowledge understand the interconnections of four STEM disciplines with a strong collaborative connection to life. Reorganizing teacher education programs to prepare future teachers to teach STEM subjects with an integrated approach is poised to create society-wide implications (Corlu, 2012). Many studies examined different variables such as attitudes of teachers and students towards STEM education; however, determining the participants' perspectives of STEM approach was thought to serve essential purposes (Yücelyiğit \& Toker, 2021).

Given the importance of integrated teaching during teacher preparation, the current policy of teacher education programs in Turkish universities holds promises to include coursework for integrated teaching knowledge and skills. After decades of implementation of standardized teacher education programs, in 2020, the Council of Higher Education granted universities the responsibility to develop their own teacher education programs. Therefore, research-based course models to help teacher candidates excel in integrated teaching knowledge for utilizing natural and active exchanges of knowledge, skills, and 
beliefs among STEM disciplines become crucial.

\section{Teacher Preparation Programs in Turkey}

In Turkey, CoHE holds the responsibility of organizing the curriculum for the teacher education programs within universities. Since 1990's, teacher preparation programs have been reformed or restructured several times without much connection to changes in K-12 education policies. A significant change in 2018-2019 academic year gave universities a strict prescription of which courses should be allocated between three different areas: subject knowledge, teaching profession knowledge, and general culture. This program structure left universities little space to make decisions about equipping their students with the necessary knowledge and skills to implement rigorous STEM education in their classrooms. In 2020, however, CoHE announced that universities now have the authority to reorganize the courses and curriculum in their teacher education programs. Through this major change of policy, many hoped that more research-based course models would be included in the programs.

The fundamental qualities of STEM education bring the content and methods of teacher education programs into the agenda. Students' understanding, success, and interest in STEM areas are strongly related to their teaching effectiveness (Keskin et al., 2018; Maher et al. 2013; Ring et. al., 2017). Therefore, teacher education to increase high-quality teaching is considered as a significant concern (Keskin et al., 2018). Considering the role of teachers for designing and implementing high-quality STEM education programs, the preparation of teachers in STEM disciplines equipped with relevant knowledge, skills, and conceptions becomes crucial (Maher et al., 2013). Previous studies have shown that teachers' conceptions about teaching and learning impact their classroom practices in science and mathematics (Lumpe et al., 2012; Roehrig \& Luft, 2004) and, therefore student's success. Teachers reflect their beliefs, views, and conceptions to the learning environment; therefore, it is crucial to understand teachers' conceptions about specific educational practices and approaches to be able to interpret the effectiveness of learning environments.

Given the importance of teachers' role in designing and implementing meaningful STEM learning experiences, research about STEM conceptions of teachers indicated that teachers have limited conceptions of STEM education. Teachers' understandings about STEM education were mostly inadequate, and they did not know how to design engaging, rigorous, and meaningful learning activities to be implemented in classroom settings (Dare et al., 2019). Considering that STEM subjects' quality and effective integration depends on teachers' knowledge and beliefs, the need for support systems to enhance teachers' understanding of STEM emerged as a key concern. Thus, several teacher educators strongly recommended to include courses about STEM education in the programs. Involving courses with a STEM education focus would also contribute to establishing a knowledge ground for high-quality integrated STEM education (English, 2016; Herschbach, 2011; Honey et al., 2014; Kelley \& Knowles, 2016).

Regarding the importance of integrated teaching experiences about STEM in teacher education programs, there is a call for interventions to build confidence about STEM subjects (Hart et al., 2009). Although the need is obvious, the research on developing STEM education skills in teacher education programs has been historically limited (Berlin \& White, 2010). The interventions mainly focused on professional education programs after graduation when teachers feel the need to improve their STEM education skills. These in-service interventions with various durations focused primarily on STEM teaching experiences and skills to teach STEM subjects with an integrated curriculum perspective (Yildirım \& Altun, 2015). Due to the well-documented need for teacher preparation to increase STEM teacher knowledge, some alternative models were implemented. Mentoring activities (Fensham, 2004), laboratory or other supplementary activities within specific courses (Akaygün \& Aslan-Tutak, 2016; Mativo \& Park, 2012; Yildırım \& Altun, 2015) were among the efforts to integrate STEM education in teacher preparation programs. 


\section{STEM: Integrated Teaching Framework}

There has been a long-time need for a research-based roadmap for teachers to integrate STEM subjects in their teaching practices. Educators recommended that training teachers with competence and motivation to contribute the programs implemented in their institutions (Akdemir, 2013). One researcher indicated that with the revisions to the teacher education programs, pre-service teachers should be encouraged to integrate global perspectives, issues, problems, and concerns into their disciplines (Tarman, 2010). It was also argued that to integrate their discipline with other disciplines pre-service teachers have to be competent in pedagogical content knowledge of these disciplines (Çolakoğlu \& Gökben, 2017). In one study, teachers reported that they did not feel confident enough in other disciplines' content and pedagogical content knowledge for an effective integration (Kurt \& Pehlivan, 2013). STEM: Integrated Teaching Framework (Corlu, 2017) was shown to provide a framework for both the implementation in the classroom and the professional development of teachers focusing on STEM disciplines, methods, and skills in an integrated way. Through Integrated Teaching Framework, teachers were shown to embrace the role of STEM education facilitators with a focus on their students' innovation literacies (Corlu, 2012). STEM: Integrated Teaching Framework aims to develop teachers' integrated lesson planning skills at the nexus of theory and practice. Authentic problem of a knowledge society (APoKS) is placed at the center of the framework. APoKS is presented as an open-ended problem within a scenario relevant to the innovation-driven life in the 21 st-century (Aşık et al., 2017). The framework emphasizes the principles for quality integration as interdisciplinarity, equity, rigor, and relevance (Corlu, 2017).

\section{Young STEM Researchers and Practitioners Program}

A unique integrated teacher education model Young STEM Researchers and Practitioners Program aims to guide undergraduate students to support their academic and professional development within the STEM education context. Beginning from the pre-service level, prospective teachers can work with teacher educators and experienced STEM Leader teachers. All participants in the program are primarily expected to be associated with STEM: Integrated Teaching Framework with their experiences. The program is directed to the students from the departments of teaching primary/secondary schools science, mathematics, and early childhood education from various universities. Participants are expected to have a strong content-knowledge, curiosity, and motivation to learn and research about STEM education. Participants worked voluntarily and allocated regular time to the participation of the program. As a result of personal applications made through face-to-face interviews, the participants have been selected. Young STEM Research and Practitioners Program was initiated in the 2016-2017 academic year, and 30 pre-service teachers from science education, mathematics education, and early childhood education programs have completed the program since then.

Throughout the program pre-service teachers work with mentors experienced in STEM education with strong academic and classroom implementation backgrounds. From this perspective, the program focuses on developing both theoretical knowledge and practical skills of future teachers. The main outcomes of the program for each teacher candidate are a completed research project and the implementation of a self-designed STEM lesson plan. The content and activities of the program are based on the Integrated Teaching Framework (Corlu, 2017). The duration of the program is one academic year, and meetings are held once a week. A typical meeting lasts for two hours. The program has mainly three parts. In the first part, the participants work on theoretical foundations of STEM: Integrated Teaching Framework to develop a shared conception of STEM education. The participants and mentors work together to design STEM lesson plans, educational materials, and a research proposal in the second part. In the final part, the implementation of lesson plans and presentation of the research results, and the final reflections about the whole program take place.

The participants of the study, who attended the program in 2016-2017 or 2017-2018 academic year engaged mainly in the following activities: 
- Presentation of a scientific research project at a scientific conference.

- Implementation of a STEM Lesson Plan with children.

- Meetings with STEM professionals and practitioners.

- Development of early STEM activities.

The current research was about the impact of the Young STEM Researchers and Practitioners Program. Through the program, supervised by STEM education mentors, senior education faculty students were recruited to be engaged in STEM research and implementation activities. The program aims to incorporate STEM integrated teaching knowledge in the teacher preparation period. Following the need to develop research-based models to support teacher candidates in terms of STEM education, the purpose of the current research was to analyze the impact of the Young STEM Researchers and Practitioners Program through participants' program experiences and STEM conceptions. The study results were expected to have implications for teacher preparation programs to develop teachers' STEM knowledge and skills.

Following are the research questions of the current study:

1. What are the experiences of Young STEM Researchers and Practitioners program participants about the elements and impact of the program on their personal and professional development?

2. How do Young STEM Researchers and Practitioners program participants rank and comment on different models of STEM education?

\section{METHODOLOGY}

\section{Research Design}

This qualitative study followed the naturalistic paradigm of inquiry to give an in-depth description and understanding of pre-service teachers' experiences as they participated in the program. Naturalistic inquiry requires studying things in their natural setting and interpreting the phenomena from the perspectives and experiences of the participants (Denzin \& Lincoln, 2008). The phenomenological research design was used to investigate how an individual makes sense of an experience and transforms this experience into consciousness (Hart et al., 2009; Merriam \& Tisdell, 2016). Specifically, the purpose of the study was to explore lived experiences of the participants who attended the Young STEM Researchers and Practitioners Program, to describe their STEM conceptualizations and perceptions about the program.

\section{Study Group}

The study group consisted of five pre-school teachers who attended the Young STEM Researchers and Practitioners Program. The participants to the program were selected via interviews and motivation letters. The interviews and motivation letters were evaluated holistically in terms of dedication, leadership potential, and attitude toward STEM disciplines. The inclusion criteria to the research were at least $90 \%$ attendance rate and completion of all the activities throughout the program. We sent invitation to research e-mails to the program participants who met the inclusion criteria, and the study group consisted of those participants who responded to the letter and attended the focus group interview. This final study group consisted of five preschool teachers (Table 1).

Preschool teachers participated in the program during their undergraduate years. The participants currently work at different private schools in İstanbul, Turkey and/or are pursuing their MA degree. Their experience ranged from zero to two years. Table 1 presents the details about the participants and their personal information. 
Table 1.

Information about Participants

\begin{tabular}{llcc}
\hline Participants & Semester & Master's degree & Teaching Experience \\
\hline Participant 1 & $2016-2017$ & & 2 \\
Participant 2 & $2016-2017$ & $*$ & 2 \\
Participant 3 & $2016-2017$ & & 2 \\
Participant 4 & $2017-2018$ & $*$ & 1 \\
Participant 5 & $2016-2017 \& 2017-2018$ & $*$ & 0 \\
\hline
\end{tabular}

\section{Data Collection}

One focus group interview was conducted to collect data about the participants' experiences about the impact of the program and their STEM conceptions. Interviews allow researchers to gain insight into the opinions of the participants (Kolb, 2012). The semi-structured focus group interview was carried out as face-to-face based on an interview protocol allowing the participants to raise different agendas. The interview protocol included two groups of questions: (1) Questions about the elements and impact of the program, (2) Questions about participants' STEM conceptions. The first group consisted of questions to guide the participants to talk about their experiences of the program and the impact of these experiences to their personal and/or professional development. The second group questions were the questions focusing on the participants' STEM conceptions. Within these questions, the participants were asked to define STEM education and rank eight given STEM education models in the order of preference. The participants were shown various models (Table 2) and asked to rank models in terms of their capacity to best express STEM education. The STEM education models were taken from Dare et al.'s (2019) study about creating a continuum of STEM models.

The interview took 100 minutes and was audio-recorded uninterruptedly with two different devices. The members of the research team guided the interview. While one member of the research team was asking questions, the other took field notes of salient points and situations during the interview. Before starting the interview, the participants were informed about the purposes and conditions of the research. All participants signed an informed consent form, including the purpose, methods, and confidentiality elements of the research. The researchers e-mailed a formal letter of appreciation to the respondents for their participation and their time.

\section{Data Analysis}

The focus group interview about the experiences and STEM conceptions of the participants was the data source for the current study. The interview was transcribed, and data in the transcripts were analyzed by using the constant comparative method. Using the constant comparative method, the researcher tries to develop concepts from data by coding and analyzing simultaneously (Taylor et al., 1998). The data analysis began with initial coding that aimed to catalog every idea that participants expressed by identifying meaningful units of data that could answer our research questions (Charmaz, 2008; Merriam \& Tisdell, 2016). The researchers read the participants' responses, identified each section of text that communicated a distinct idea or ideas, and assigned code(s) that captured these ideas (Birks \& Mills 2011). The researchers discussed every coding until they reached a consensus. By this way, the analyses continued iteratively and collaboratively.

To formulate the codes and categories a combination of pre-determined and emerging codes was used. For prior determination of the codes, we used the work of Ball et al. (2008) for pedagogical content knowledge and STEM: Integrated Teaching Framework (Corlu, 2017) for knowledge of content and teaching section.

To analyze the STEM education model rankings of the participants, a frequency matrix based on the rankings of the participants was prepared to report more desirable (first four models in the rankings) and less desirable (final four models in the rankings) STEM education models. A common continuum was also developed using the mode values in terms of assigned ranks. The researchers also analyzed and 
reported evidence on participants' reasoning by ranking the STEM models from the focus group interview data.

Table 2.

Eight Models of STEM Education in The Study Conducted by Dare, Ring-Whalen, \& Roehrig, 2019. STEM education model code Image of model

A - STEM as an Acronym

\section{S T E M}

B - Real-World Problem Solving as Context

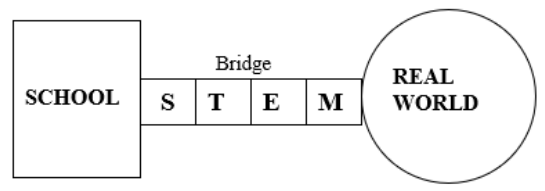

$\mathrm{C}-$ Science as Context

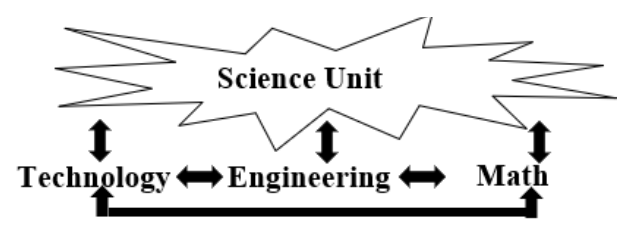

D - Science, Technology, Engineering, and Mathematics as Separate Disciplines

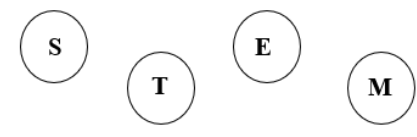

E - Integrated Disciplines

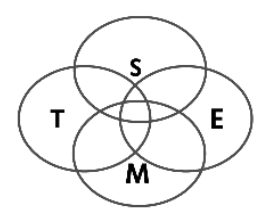

F - Engineering Design Process as Context

G - Science and Engineering Design Process as Context

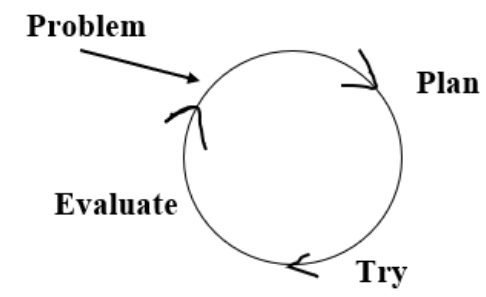

$\mathrm{H}$ - Engineering as Context

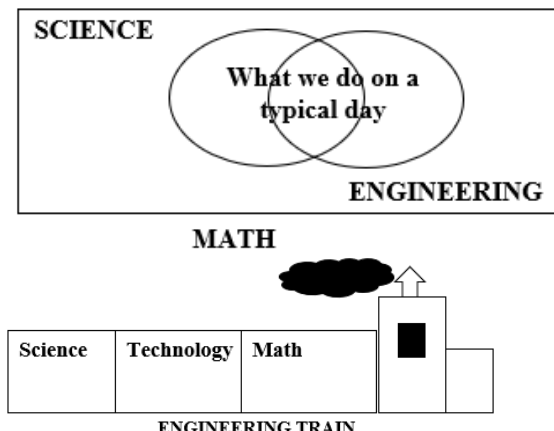

ENGINEERING TRAIN 


\section{Reliability and Validity}

In qualitative studies, the reliability and validity of the results are expressed with the concept of trustworthiness. To ensure the trustworthiness of the qualitative data, the researchers used several elements: prolonged interviews, peer debriefing, member check, researcher reflexivity, and working hypothesis.

The researchers conducted a prolonged focus group interview which lasted approximately two hours. During the interview one researcher took field notes to be consulted through the coding and categorization process when needed. A peer-debriefer must be "someone who is in every sense the inquirer's peer, someone who knows a great deal about the substantive area of the inquiry and the methodological issues" (Lincoln \& Guba, 1985). The peer debriefer in the study helped the researchers with methodological issues, and the researchers discussed their findings, their interpretations of data, and possible future directions with the peer debriefer.

To ensure credibility, dependability, and confirmability of the research (Lincoln \& Guba, 1985) member checking procedure was applied. During the interviews, the participants were asked to clarify and confirm their answers. After the data collection and analysis, the researchers contacted the participants and shared their initial findings with them. All participants confirmed the categories and themes that emerged as the representation of their statements. For the researcher reflexivity, one researcher kept a reflexive journal covering detailed notes about the research process. The researchers' experiences throughout the research process were also included in the reflexive notes. Tasks and specific stages of the research process were listed, and notes were taken.

Further to ensure the confidentiality of the participants, the researchers did not refer to the participants with their name and avoided details that could reveal the participants' identity. Participation in the study was voluntary. The participants were informed about the details of data collection and the use of data to protect their confidentiality.

The working hypothesis of the current study is limited to a specific context but maybe generalized from the findings of the study (Erlandson et al., 1993). The context of the study is the effect of the Young STEM Researchers and Practitioners Program to participate teachers' academic and professional development and their STEM conceptions. In other words, the working hypothesis of the study is that the program's activities contributed positively to participants' academic and professional development and STEM conceptions.

The study was approved by Bahçeşehir University Research and Publication Ethics Committee with decision number 10.02.2021, 2021/02/20.

\section{FINDINGS}

\section{Findings about the First Research Question: Program Experience}

The first research question focused on the participants' experiences within Young STEM researchers and practitioners program. The participants discussed about the main features of the Young STEM researchers and practitioners program and the impact of the program to their personal and/or professional development. Codes and categories for the first research question are presented in Table 3. 
Table 3.

Categories and Codes for Program Experience

\begin{tabular}{lll}
\hline Categories & \multicolumn{2}{l}{ Codes } \\
\hline Raised awareness for STEM education & $\bullet$ & Need for professional development \\
& - & Need for STEM education \\
& - & Need for developing a common school culture \\
Development of integrated teaching & - & Attitudes towards teaching mathematics and \\
knowledge & - & Subject matter knowledge \\
Program elements & - & Pedagogical content knowledge \\
& - & Supportive conditions \\
& - & Collective learning \\
& - & Recommendations \\
\hline
\end{tabular}

\section{Raised awareness for STEM education}

When asked to elaborate their views about their personal and professional development after their participation in the program, the participants firstly discussed the awareness they developed about STEM education. Before participation in the program, the participants did not have any experience with STEM education. As they participated in the program, the participants started to see the need to improve their knowledge and skills about STEM education. One participant argued that "We learned that the notion of STEM exists and experienced that these interdisciplinary topics come together to construct a fruitful environment for children," another participant added on this by arguing:

\footnotetext{
"We came without knowing much, but as my other friend said, this was an awareness for both parties, especially for early STEM, while there was nothing in this area, what we still had was a great awareness and advantage."
}

Another participant also evaluated the participation as an advantage by saying:

"Science and Mathematics, Technology raise the idea that these are interdisciplinary, (but) there may be a deficiency in combining these fields. I think it was an advantage for me to realize this and do a little more research in our own profession."

The participants also saw the need to be more exposed to STEM teaching experience in the teacher preparation programs. For example, one participant argued that:

"But I wish we were more exposed to such things, at least during university education, if I had at least or more opportunities to research these concepts, there had to be a lesson for it because you are learning (in the lesson). It made you think about this a little bit, I am still thinking about it."

After they became aware of the notion of the STEM education, the participants also developed thoughts about the implementation with students. The participants connected the knowledge and skills they learned through the program with the professional knowledge they gained in the university. For example, one participant offered STEM education as a solution to problems resulted from teacher-centered education:

\footnotetext{
"Therefore, the more we think about it, the more (we think about) different and useful things to get out of that classic thing, the more different and useful things emerge. I think the most interesting thing about STEM is that it is interesting and makes one say, "let me do it", it makes one say, "it will work", the side that makes you say it will work."
}

The participants gave high credit to the implementation of STEM education and were sure it would benefit them and their students. One participant defined her trust in STEM education by saying "I feel relieved that I want to do this in my class when I do something about STEM." 
When the participants discussed the implementation of STEM, they underlined the need for change in school culture about STEM education. Especially for the pre-school level, the participants emphasized the importance of creating learning environments that allow quality implementation by integrating the disciplines, especially for the pre-school level. Participants' expressions such as "there is no such culture at all, I am sure there are many schools that finish pre-school without doing any experiments." and "we must question the school culture: I (schools) have done too many things, but it does not work, we (schools) have to try different things" pointed out their ideas about the importance of schools' decisions about the implementation of STEM education.

Participants' answers indicated that their attitudes about teaching mathematics and science have changed positively after participating in the program. The participants stated that before the program entrance, they were not confident about their background in mathematics and science, which was also apparent in their statements about subject-matter knowledge. After the participation, however, they felt more encouraged to implement STEM education in their classrooms. For example, one participant talked about the courage to teach STEM in the classroom: "You know, courage, such a spark of hope comes to you. Maybe we need a little more courage, not 5 minutes and 10 minutes but an activity, two activities, which I will do no matter what, with courage by 'being sure of its process.' It would be great for me to see it, for example, by copying it, demonstrating what I saw.". One participant also pointed out that observing and experiencing STEM implementation changed their attitudes towards teaching mathematics and science: "At least, it was nice to see that these works may have a result, that they can work, even if we do not have the background, even if they are difficult at the moment."

\section{Development of integrated teaching knowledge}

During the focus group interview, the participants also acknowledged their development in the knowledge of teaching STEM. From their statements, we can infer that they were aware of the main features of STEM: Integrated Teaching Framework, developed their knowledge about mathematics and science disciplines and thought of ways to teach the content to students. We summarized these development areas by using Ball et al. (2008) and STEM: Integrated Teaching Framework (Corlu, 2017).

Subject matter knowledge, to begin with, was one of the codes that emerged under this category. The participants firstly acknowledged that they lacked subject-matter knowledge before participating in the program, especially for mathematics and science. This lack of knowledge was expected because the participants were early childhood teachers. The participants mostly attributed their lack of knowledge to the lack of prior learning experiences: "for example, simple machines. This is a basic science and physics subject, I remember this topic from high school, I also did not understand the subject then", "we made a presentation with our group of friends at the university as part of the mathematics lesson, but it was like a project assignment within the lesson." and "science was a field we left very far away, so our education at the university was not full of science and mathematics.". These statements pointed out that the participants were not confident in their content knowledge in mathematics and science. The participants were also aware that attending the program was not enough to develop the content knowledge; however, now they know how to do research to develop their content knowledge and use it to provide STEM education for children.

To connect subject matter knowledge, the participants also discussed the importance of strategies to teach content to the students. They mainly emphasized the content and teaching dimension of pedagogical content knowledge. The participants used the elements and procedures of STEM: Integrated Teaching Framework as the strategies to teach content to the students. They mostly underlined the Authentic Problem of Knowledge Society in their assertions:

"There is real-life problem. Our problems are not solved at once, we prepare us for it, we encounter it, we accept it, we produce solutions, we apply it. We look, we give more feedbacks if it needs 
revision" and "it is also very important that it is a real-life problem because it is a real-life problem for me as well. After all, I have never encountered such a problem before."

These statements were evidence that the participants consider the real-life problem as the basis of STEM education. As a matter of fact, in their further assertions, they explained the process of STEM education by giving reference to Authentic Problems of Knowledge Society. For example, one participant's statement indicated that the participant sees STEM education as an iterative process with an idea at its core:

"First they do something about that idea, whatever it is, and at the end of it, they actually become able to do that activity. That process is also very important because the child creates that thing and creates that idea and culture. It is important to me because it progresses by adding something rather than a one-time event."

Other participants also underlined the importance of process, and they can distinguish STEM education process from doing isolated science experiments or do it yourself projects:

"Actually, STEM adds a new look from here, it isn't, like, these are the materials, sit and do that, it is to accept that it doesn't work anymore, okay maybe we will continue this at school, but you know, that might be the alternative to what doesn't work, it really will attract kids, it will work. Indeed, it could be a real-life problem and trying something out and getting it to realize it by themselves."

The participants also discussed the importance of making the content accessible for the students. Their statements emphasized that they also gained experience adapting content to the children's lives and developmental levels. In other words, they were concerned about the connection between content and the students:

"You know, how can we understand it as a science and then adapt it to the age group we will address, and we will eventually do this effectively and we have a claim that it is a real-life problem. I wonder if children could get into it".

The participants primarily argued the support of creating the characters to reach the children in early childhood level.

"We had The Beaver. This character is a little different, this is not like, a character appears in one activity and another character appears in another activity. It was always like a journey of the Beaver. I think it was a good idea to (make children) internalize it more."

This statement showed that by acknowledging the importance of the character, the participants were also aware of making the iterative process of STEM more understandable to the students.

\section{Program elements}

The participants attributed their development to some significant elements of the program. One of them was the products they created collaboratively during the program. The primary product the participants consistently argued about are the early STEM education books they created together. The participants defined this experience as a source of pride and as an experience through they developed:

\footnotetext{
"Obviously, it was excited to see our names (on the books), there was also an effort to create and implement a product because we were students. I remember that we were excited when the actual product first came out."
}

Another participant also got excited when she first saw the books they created: "for example, we always said we were working for the book, but it was precious to have a printed, written and illustrated book." Working on a product together pushed them to research the content and strategies within STEM 
education. The participants mainly developed their content knowledge using books and internet resources, as well as asking their peers:

"We asked .... for the content, and it was very comforting for us, we were pre-school teachers, but her field was science. She, however, was not experienced in working with young children."

The view of this participant showed that they collaborated to create a quality product. By knowing the details of STEM education, the participants also argued that they did more research to fill the gaps in the areas. For example, one participant said that "Science, mathematics, technology, there may be a deficiency in combining these fields. I think it was an advantage for me to realize this and do a little more research in our profession."

The participants also valued the implementation of STEM education, which was evident both in the participants' definitions of their experiences and recommendations to improve the program. The participants acknowledged that they found opportunities to implement. However, they wanted to apply more STEM activities, and lesson plans. The participants also wanted to network with more practicing teachers implementing STEM lesson plans in their classrooms.

\section{Findings of the Second Research Question: STEM Conceptions}

To understand the STEM conceptions of the participants, we showed them, eight visual models. The participants organized the STEM models in a continuum from the most desirable to the least desirable model. As the first step to understanding participants' STEM conceptions, we generated a frequency matrix (Table 4) showing how often the participants placed a model in each of the eight positions, with position 1 representing the most and position 8 representing the less desirable model.

Table 4.

Frequency Matrix of STEM Models

\begin{tabular}{|c|c|c|c|c|c|c|c|c|c|c|}
\hline & \multicolumn{8}{|c|}{ Position in continua } & \multicolumn{2}{|c|}{ Percentage frequency } \\
\hline & \multicolumn{4}{|c|}{ More desirable side } & \multicolumn{4}{|c|}{ Less desirable side } & \multirow{2}{*}{$\begin{array}{c}\text { In more } \\
\text { desirable side }\end{array}$} & \multirow{2}{*}{$\begin{array}{c}\text { In less desirable } \\
\text { side } \\
\%\end{array}$} \\
\hline & 1 & 2 & 3 & 4 & 5 & 6 & 7 & 8 & & \\
\hline Model A & 0 & 0 & 0 & 0 & 1 & 0 & 1 & 3 & 0 & 100 \\
\hline Model B & 2 & 1 & 1 & 1 & 0 & 0 & 0 & 0 & 100 & 0 \\
\hline Model C & 0 & 0 & 0 & 1 & 2 & 1 & 1 & 0 & 20 & 80 \\
\hline Model D & 0 & 0 & 0 & 0 & 0 & 1 & 3 & 1 & 0 & 100 \\
\hline Model E & 1 & 0 & 1 & 0 & 1 & 2 & 0 & 0 & 40 & 60 \\
\hline Model F & 1 & 1 & 2 & 1 & 0 & 0 & 0 & 0 & 100 & 0 \\
\hline Model G & 1 & 1 & 0 & 0 & 1 & 1 & 0 & 1 & 40 & 60 \\
\hline Model H & 0 & 2 & 1 & 2 & 0 & 0 & 0 & 0 & 100 & 0 \\
\hline
\end{tabular}

In Table 4, besides the specific positions, we also divided the continuum in half to represent less and more desirable models, through which we could understand to which side a model belonged to according to participants. The percentages of the models in each half of the continuum pointed out that all (100\%) participants put models $\mathrm{B}, \mathrm{F}$, and $\mathrm{H}$ on the more desirable side, whereas models $\mathrm{A}$ and $\mathrm{D}$ were on the less desirable side in all the participants' continua.

Using the frequencies of the models in specific positions, we identified a common continuum concerning the mode value of each model per position from participants' continua (Table 5). Model G-Science and engineering process as a context was not a mode for any position; it was found in various positions, but mainly on the more desirable side. 
Table 5.

\begin{tabular}{|c|c|c|c|c|c|c|c|}
\hline Pos.1 & Pos. 2 & Pos. 3 & Pos.4 & Pos.5 & Pos.6 & Pos.7 & Pos. 8 \\
\hline $\begin{array}{l}\text { B. Real- } \\
\text { World } \\
\text { Problem } \\
\text { Solving as }\end{array}$ & $\begin{array}{l}\text { H. } \\
\text { Engineering } \\
\text { as context }\end{array}$ & $\begin{array}{l}\text { F. EDP } \\
\text { as a } \\
\text { context }\end{array}$ & $\begin{array}{l}\text { H. } \\
\text { Engineering } \\
\text { as context }\end{array}$ & $\begin{array}{l}\text { C. } \\
\text { Science } \\
\text { as } \\
\text { context }\end{array}$ & $\begin{array}{l}\text { E. } \\
\text { Integrated } \\
\text { disciplines }\end{array}$ & $\begin{array}{l}\text { D. STEM as } \\
\text { separate } \\
\text { disciplines }\end{array}$ & $\begin{array}{l}\text { A. STEM } \\
\text { as } \\
\text { acronym }\end{array}$ \\
\hline
\end{tabular}

The continuum in Table 5 shows that the participants mostly perceived STEM within a real-world context (Model B). This was also evident in their interview, where they emphasized the importance of real-world problems in STEM implementations. The participants also valued the engineering and engineering design process as a context for STEM (Model F and Model H). Model A and Model D were in the less desirable positions in all participants' continua showing that the participants did not perceive STEM as separate disciplines or a meaningless acronym.

We also used interview data to understand participants' rankings and collect deeper evidence for their STEM conceptions. We presented the interview data in the least (Model A, Model D) and most (B, F, H) desirable models.

\section{Least desirable models}

The participants evaluated Model A and D as the least desirable models because they emphasized the four disciplines being separate. In both models, they looked for more connections in the disciplines. For example, one participant's idea about model A is, "Do you know why I put it to the end because they located it so separately, it looks like they (the disciplines) are very different. It could be a little more intertwined". Three participants putting model A in the last positions showed that they perceived STEM education beyond the acronym. When evaluating model $\mathrm{D}$, participants did not prefer to see the disciplines separated by circular areas. The participants perceived these circular areas as borders to symbolize that the disciplines are different from each other. Therefore, they found model D as least desirable. The participants saw the lack of connection and unclear integration as common aspects of the least desirable models.

\section{Most desirable models}

The participants evaluated models $\mathrm{B}, \mathrm{F}$, and $\mathrm{H}$ as the most desirable models depicting STEM. The models seemed more integrated by using either engineering, engineering design process, or real-world problems as a context. It was not surprising that the participants ranked model B, real-world problem solving as a context, as the most desirable model. When describing their experiences, the participants frequently discussed that real-world problems play a crucial role in STEM education. Therefore, it is possible to connect this perception to participants' program experiences. The participants liked model B because it depicts that STEM education brings the real world to school:

\footnotetext{
"Because my problem is to connect the school with the real life through STEM because it is with the school, because the problem of the school is being a very artificial system that is very detached from real life."
}

Moreover, the participants also gave importance to seeing all four disciplines in the model and the realworld context.

Although there was a consensus about model B, the participants thought differently about model F. They all selected model $\mathrm{F}$ for the desirable ranks by noting some undesirable aspects of the model. What the participants liked about model $\mathrm{F}$ is that it signifies a methodology for teaching STEM. The participants discussed that model $\mathrm{F}$ is process-oriented and provides specific stages for implementation. This idea 
was evident in two participants' opinions: "It shows how the lessons can be applied" and "Isn't that the STEM anyway, so it's a preparation. This is STEM's method, and there will be a readiness, it will be tried, evaluated, and done again." Some participants argued against these opinions by saying the model is not STEM specific and the content is not specified. Hearing these arguments, one participant emphasized the importance of process again by doing STEM activities:

\begin{abstract}
"But does the content matter? It could be Amsterdam houses or any topic from everyday life, it could be a teamwork problem, it could be anything. But if what STEM wants to give is how they should solve that problem, if it is the development of mathematical thinking and those functions, if what we are trying to do through STEM is not teaching physics, but teaching thinking that way, I think we are teaching to think like that."
\end{abstract}

We can conclude from these opinions that although some of the participants found the model as not being specific and not focusing on content, they liked that the model shows a process to implement STEM activities and brings skills to the forefront.

Similar to model F, participants' opinions about model H were varied. They were mostly positive about engineering being a context for STEM educationbecause the participants saw engineering as a discipline where people use both their skills and content knowledge in other disciplines such as mathematics and science:

"Because under the umbrella of engineering, because the engineers are there to solve a problem, to make life easier. That is why I think engineers learn both science, mathematics, and technology."

One participant liked the idea of the train because she thought that a train would arrive somewhere, and this is a positive aspect:

"It was the train that drew my attention because there is a place where the train wants to arrive.

That thing I just said, how you reached the point matters, that's how you arrive using the wagons."

Following the line of thought for model F, the participants preferred to see the STEM implementation process in an initial position within the models. Some of the participants were not convinced that the model clarifies the integration of disciplines enough. They thought that using engineering as a context or as a tool to implement STEM does not imply a quality integration. For example, one participant asked: "But is engineering everything? So, is it the tool? Do we need engineering just because it is a vehicle?" These questions showed that the participant is also dissatisfied with engineering being dominant. Another participant disliked that the model does not depict a cycle. To summarize participants' opinions about model $\mathrm{H}$, they mostly perceived the model as desirable considering engineering as a means to implement STEM education. However, they also noted that the model is engineering dominant and does not show a cyclical process.

\title{
DISCUSSION AND CONCLUSION
}

We focused on two research questions to understand participants' experiences about the Young STEM researchers and practitioners' program. The first research question aimed to describe participants' professional development gains to their participation and program elements. Through the second research question, we explored participants' STEM education conceptions by asking them to rank different models of STEM education.

The findings of the research question pointed out that the participants raised their awareness of STEM education and implementations. The participants reported that with being aware of STEM education notion, now, they can see the need to develop themselves in terms of STEM education, especially they 
need to develop their science and mathematics teaching practices. The Young STEM researchers and practitioners program participants became aware that their prior experiences about teaching mathematics and science were not enough, and they had to develop themselves to implement quality STEM education. Participants' increased awareness of STEM education may be related to the content and activities of the program. The engagement in both theory and practice of STEM education may have led the participants to reconsider their STEM education notions. The participants can transfer their increased awareness to discuss broader issues about STEM education. More specifically, they advocate using STEM education to change the traditional methods used in the classroom. They can approach STEM education from a pedagogic perspective, different than political and popular approaches. The finding that the participants have a pedagogical understanding of STEM can be interpreted as a shred of evidence that they found an opportunity to concentrate on quality teaching-learning aspects of STEM education in the program. The program's theoretical foundation, the integrated teaching project, is also categorized under the pedagogical interpretation of STEM (Corlu, 2017; Corlu et al., 2014). Embracing a pedagogical interpretation of STEM, the participants are also aware that the implementation of STEM can be challenging without establishing a common culture throughout the school.

The participants also asserted that they developed themselves in terms of their attitudes to teaching science and mathematics. Similar findings have been observed in other studies with STEM professional development interventions. For example, Akaygün and Aslan-Tutak (2016) found that after a professional development activity with a science inquiry and engineering design process focus, preservice and in-service teachers reported having greater confidence that their science teaching will have positive outcomes. As pre-school teachers, participants' positive attitudes may also resulted from the continuous exposure to the math and science content throughout the program's activities. Positive change in participants' attitudes and self-efficacy beliefs is essential because if teachers are confident with their pedagogy, they will feel comfortable teaching the content (Bursal \& Paznokas, 2006). Besides their teaching performance, teachers' self-efficacy and attitudes to teaching are also related to their commitment, persistence, and motivation to implement novel educational approaches (Gabriele \& Joram, 2007; Ross \& Bruce, 2007). With our participants being pre-school teachers, positive attitude changes promise to lead quality teaching practices in early childhood settings.

The second category emerged for the first research question provides a more detailed understanding of participants' developments in their integrated teaching knowledge. To describe participants' gains in the integrated teaching knowledge, we looked for evidence in the development of subject-matter and pedagogical content knowledge. Participants' assertions indicated that the participants developed both in subject-matter and pedagogical content knowledge for teaching STEM. This finding may be related to the STEM lesson planning element of the program. By designing the STEM lesson plans, teacher candidates may have improved their knowledge about methodologies and students' responses about the lesson plan. Despite the gap in their teacher preparation programs, early childhood teachers appreciate the value of providing quality STEM experiences to young children (Hammack \& Ivey 2017; Linder et al., 2016; Saçkes 2014; Torquati et al., 2013). Research about the implementation of integrated STEM teaching knowledge indicates that K-12 teachers are not very competent in terms of designing and implementing engaging, rigorous, and meaningful activities in their classrooms (English, 2016; Herschbach, 2011; Honey et al., 2014; Kelley \& Knowles, 2016; Keskin et al., 2018). Early childhood teachers, in particular, are not familiar with STEM education and cannot evaluate what learning opportunities STEM education can offer (Abanoz \& Deniz, 2021). For early childhood teachers, the lack of competency and awareness in STEM education may result from inadequate professional preparation in math and science education (Brenneman et al., 2019; Greenfield et al., 2009).

The participants reported that with the help of the program elements, they gained experience in mathematics and science content knowledge. The participants were also aware of the lack of prior experience regarding science and mathematics teaching. From this point, we can attribute content knowledge development to the elements of the program. To develop pedagogical content knowledge, the participants frequently stressed the real-world problem and the importance of the learning process. This finding implies that the participants think about developing authentic contexts for STEM teaching- 
learning activities. Although there is a body of research indicating that early childhood teachers are less accustomed to planning integrated activities that are related to science, technology, and mathematics (Greenfield et al., 2009; Moomaw, 2013), the participants report their understanding of two essential elements in terms of teaching integrated STEM. Integrating STEM disciplines within an authentic context is a difficult task for teachers (Başaran, 2018; English, 2016; Herschbach, 2011; Rinke et al., 2016), however, the program participants expressed their readiness to focus on the STEM process through a real-world problem context. It was also expected that the participants would discuss the importance of scientific inquiry and project-based learning for integration and mention integration principles, such as equity, rigor, and relevance.

Within their STEM model rankings, the models they selected as less desirable were the two models, which depict the STEM disciplines separately, and only the acronym of STEM was used (Model A and Model D). In Dare et al., (2019) study, teachers also set aside the model A and D first by describing them as too vague, lacking detail and information related to integrating between disciplines. The preferences of the research participants indicate that they see STEM beyond the acronym. Bybee (2013) also points out that the STEM acronym gives little clue about the process, therefore teaching practices and instructional approaches within STEM education should be the central concern of educators. The models integrating STEM disciplines around real-world problems (Model B), engineering (Model H) or engineering design process (Model F) were ranked as the most desirable models by the participants. The participants' selection of real-world contexts for the integration may result from the program's emphasis on the authentic problems of knowledge society as the core of integrated STEM education. The engineering contexts were also preferred most by participants, indicating that the participants value concrete contexts for the integration and teaching process. Engineering and engineering design processes are frequently used as the most concrete and straightforward processes in early childhood settings. In relevant studies, engineering is associated with the creative problem-solving process, which results in a practical and valuable solution. Engineering is also linked with a series of steps to prepare for and execute projects (Mativo \& Park, 2012, Rockland et al., 2010). From a different perspective, in Dare et al.'s (2019) study, teachers did not select the engineering-oriented models as the most desirable. The authors associated this finding with the teachers' desire to see models capturing more flexible integration approaches that do not highlight a specific discipline.

Research-based teacher education models offer student teachers opportunities to develop their STEM conceptions and integrated teaching knowledge. Young STEM researchers and practitioners program can be evaluated as a developing model to be incorporated in teacher education programs. Further research can explore how pre-service teachers form their STEM conceptions and develop their integrated teaching knowledge.

\section{REFERENCES}

Abanoz, T., \& Deniz, Ü. (2021). Okul öncesi dönemde STEM yaklaşımı ve bu yaklaşıma uygun fen etkinlikleri: Sahadan görüşler [STEM in early childhood education and STEM based science education activities: Views from the field]. Gazi University Journal of Gazi Educational Faculty, 41(1), 1-24.

Akaygun, S., \& Aslan-Tutak, F. (2016). STEM images revealing stem conceptions of pre-service chemistry and mathematics teachers. International Journal of Education in Mathematics, Science and Technology, 4(1), 56-71. https://doi.org/10.18404/ijemst.44833

Akdemir, A. S. (2013). Türkiye'de öğretmen yetiştirme programlarının tarihçesi ve sorunları [History of teacher training programmes and their problems in Turkey]. Electronic Turkish Studies, 8(12), 15-28.

Aşık, G., Doğança-Küçük, Z., Helvacı, B., \& Corlu, M. S. (2017). Integrated teaching project: A sustainable approach to teacher education. Turkish Journal of Education, 6(4), 200-215. https://doi.org/10.19128/turje.332731

Ball, D. L., Thames, M. H., \& Phelps, G. (2008). Content knowledge for teaching: What makes it special. Journal of teacher education, 59(5), 389-407. https://doi.org/10.1177/0022487108324554 
Başaran, M. (2018). Okul öncesi eğitimde STEM yaklaşımının uygulanabilirliği (Eylem araştırması) [The applicability of STEM approach in preschool education (Action research)] (Unpublished doctoral dissertation), Gaziantep University Institute of Educational Sciences.

Berlin, D. F., \& White, A. L. (2010). Pre-service mathematics and science teachers in an integrated teacher preparation program for grades 7-12: A 3-year study of attitudes and perceptions related to integration. International Journal of Science and Mathematics Education, 8(1), 97-115. https://doi.org/10.1007/s10763-009-9164-0

Birks, M., \& Mills, J. (2011). Grounded theory: A practical guide. Sage. https://doi.org/10.7748/nr.23.5.42.s10

Brenneman, K., Lange, A., \& Nayfeld, I. (2019). Integrating STEM into pre-school education; designing a professional development model in diverse settings. Early Childhood Education Journal, 47(1), 15-28. https://doi.org/10.1007/s10643-018-0912-z

Bursal, M., \& Paznokas, L. (2006). Mathematics anxiety and pre-service elementary teachers' confidence to teach mathematics and science. School Science and Mathematics, 106(4), 173-180. https://doi.org/10.1111/j.1949-8594.2006.tb18073.x

Bybee, R. W. (2013). The case for STEM education: Challenges and opportunities. NSTA press. https://doi.org/10.2505/9781936959259

Charmaz, K. (2008). Reconstructing grounded theory. In P. Alasuutari (Ed.), The Sage handbook of social research methods (pp. 461-478). Sage Publications. https://doi.org/10.4135/9781446212165.n27

Çolakoğlu, M. H., \& Gökben, A. G. (2017). Türkiye'de eğitim fakültelerinde FeTeMM (STEM) çalışmaları [STEM studies in Turkish faculties of education]. Journal of Research in Informal Environments, 2(2), 4669.

Corlu, M. S. (2012). A pathway to STEM education: Investigating pre-service mathematics and science teachers at Turkish universities in terms of their understanding of mathematics used in science (Unpublished doctoral dissertation). Texas A\&M University.

Corlu, M. S. (2014). Call for manuscripts on STEM education. Turkish Journal of Education, 3(1), 4-10. https://doi.org/10.19128/turje.181071

Corlu, M. S. (2017). STEM: Bütünleşik öğretmenlik çerçevesi [STEM: Integrated teaching framework]. In M. S. Corlu \& E. Çallı (Eds.), STEM Kuram ve Uygulamaları (pp. 1-10). Pusula.

Corlu, M. S., Capraro, R. M., \& Capraro, M. M. (2014). Introducing STEM education: Implications for educating our teachers in the age of innovation. Eğitim ve Bilim, 39(171), 74-85.

Dare, E. A., Ring-Whalen, E. A., \& Roehrig, G. H. (2019). Creating a continuum of STEM models: Exploring how K-12 science teachers conceptualize STEM education. International Journal of Science Education, 41(12), 1701-1720. https://doi.org/10.1080/09500693.2019.1638531

Denzin, N. K., \& Lincoln, Y. S. (2008). Introduction: The discipline and practice of qualitative research. In N. K. Denzin \& Y. S. Lincoln (Eds.), Strategies of qualitative inquiry (pp. 1-43). Sage Publications.

English, L. D. (2016). STEM education K-12: Perspectives on integration. International Journal of STEM education, 3(1), 1-8. https://doi.org/10.1186/s40594-016-0036-1

Erlandson, D. A., Harris, E. L., Skipper, B. L., \& Allen, S. D. (1993). Doing naturalistic inquiry: A guide to methods. Sage.

Fensham, P. J. (2004). Defining an identity: The evolution of science education as a field of research (Vol. 20). Springer. https://doi.org/10.1007/978-94-010-0175-5

Gabriele, A. J., \& Joram, E. (2007). Teachers' reflections on their reform-based teaching in mathematics: Implications for the development of teacher self-efficacy. Action in Teacher Education, 29(3), 60-74. https://doi.org/10.1080/01626620.2007.10463461

Greenfield, D. B., Jirout, J., Dominguez, X., Greenberg, A., Maier, M., \& Fuccillo, J. (2009). Science in the preschool classroom: A programmatic research agenda to improve science readiness. Early Education and Development, 20(2), 238-264. https://doi.org/10.1080/10409280802595441

Hammack, R., \& Ivey, T. (2017). Examining elementary teachers' engineering self-efficacy and engineering teacher efficacy. School Science and Mathematics, 117(1-2), 52-62. http://dx.doi.org/10.1111/ssm.12205

Hart, L. C., Smith, S. Z., Swars, S. L., \& Smith, M. E. (2009). An examination of research methods in mathematics education (1995-2005). Journal of Mixed Methods Research, 3(1), 26-41. https://doi.org/10.1177/1558689808325771

Herschbach, D. R. (2011). The STEM initiative: Constraints and challenges. Journal of STEM Teacher Education, 48(1), 96-122. https://doi.org/10.30707/JSTE48.1Herschbach

Honey, M., Pearson, G., \& Schweingruber, H. A. (Eds.). (2014). STEM integration in K-12 education: Status, prospects, and an agenda for research (Vol. 500). Washington, DC: National Academies Press. https://doi.org/10.18260/1-2--20673

Kelley, T. R., \& Knowles, J. G. (2016). A conceptual framework for integrated STEM education. International Journal of STEM education, 3(1), 1-11. https://doi.org/10.1186/s40594-016-0046-Z 
Keskin, Ö., Corlu, M. S., \& Ayas, A. (2018). Voicing mathematics teachers: a holistic overview of their early career challenges. Educational Sciences: Theory and Practice, 18(2), 331-371. https://doi.org/10.12738/estp.2018.2.0025

Kolb, S. M. (2012). Grounded theory and the constant comparative method: Valid research strategies for educators. Journal of Emerging Trends in Educational Research and Policy Studies, 3(1), 83-86.

Kurt, K., \& Pehlivan, M. (2013). Integrated Programs for Science and Mathematics: Review of Related Literature. International Journal of Education in Mathematics, Science and Technology, 1(2), 116- 121.

Lincoln, Y., \& Guba, E.G. (1985). Naturalistic Inquiry. Sage Publications.

Linder, S. M., Emerson, A. M., Heffron, B., Shevlin, E., Vest, A., \& Eckhoff, A. (2016). STEM use in early childhood education: Viewpoints from the field. YC Young Children, 71(3), 87-91. https://doi.org/10.2307/ycyoungchildren.71.3.87

Lumpe, A., Czerniak, C., Haney, J., \& Beltyukova, S. (2012). Beliefs about teaching science: The relationship between elementary teachers' participation in professional development and student achievement. International journal of science education, 34(2), 153-166. https://doi.org/10.1080/09500693.2010.551222

Maher, P. A., Bailey, J. M., Etheridge, D. A., \& Warby, D. B. (2013). Pre-service teachers' beliefs and confidence after working with STEM faculty mentors: An exploratory study. Teacher Education and Practice, 26(2), 266-284.

Mativo, J. M., \& Park, J. (2012). Innovative and creative K-12 engineering strategies: implications of pre-service teacher survey. Journal of STEM Education: Innovations and Research, 13(5), 26-29.

Merriam, S. B., \& Tisdell, E. J. (2016). Qualitative Research: A Guide to Design and Implementation. JosseyBass.

Ministry of National Education (2019). PISA 2018 Türkiye ön raporu. [PISA 2018-Turkey Preliminary Report]. http://www.meb.gov.tr/meb_iys_dosyalar/2019_12/03105347_PISA_2018_Turkiye_On_Raporu.pdf

Moomaw, S. (2013). Teaching STEM in the early years: Activities for integrating Science, Technology, Engineering, Mathematics. Redleaf Press.

National Research Council. (2011). Successful K-12 STEM education: Identifying effective approaches in science, technology, engineering, and mathematics. National Academies Press.

Ring, E. A., Dare, E. A., Crotty, E. A., \& Roehrig, G. H. (2017). The evolution of teacher conceptions of STEM education throughout an intensive professional development experience. Journal of Science Teacher Education, 28(5), 444-467. https://doi.org/10.1080/1046560X.2017.1356671

Rinke, C. R., Gladstone-Brown, W., Kinlaw, C. R., \& Cappiello, J. (2016). Characterizing STEM teacher education: Affordances and constraints of explicit STEM preparation for elementary teachers. School Science and Mathematics, 116(6), 300-309. https://doi.org/10.1111/ssm.12185

Rockland, R., Bloom, D. S., Carpinelli, J., Burr-Alexander, L., Hirsch, L. S., \& Kimmel, H. (2010). Advancing the "E" in K-12 STEM education. Journal of Technology Studies, 36(1), 53-64.

Roehrig, G. H., \& Luft, J. A. (2004). Constraints experienced by beginning secondary science teachers in implementing scientific inquiry lessons. International Journal of Science Education, 26(1), 3-24. https://doi.org/10.1080/0950069022000070261

Ross, J., \& Bruce, C. (2007). Professional development effects on teacher efficacy: Results of randomized field trial. The Journal of Educational Research, 101(1), 50-60. https://doi.org/10.3200/JOER.101.1.50-60

Saçkes, M. (2014). How often do early childhood teachers teach science concepts? Determinants of the frequency of science teaching in kindergarten. European Early Childhood Education Research journal, 22(2), 169184. https://doi.org/10.1080/1350293X.2012.704305

Sanders, M. (2009). STEM, STEM education, STEMmania. Technology Teacher, 68(4), 20-26.

Tarman, B. (2010). Global perspectives and challenges on teacher education in Turkey. International Journal of Arts \& Sciences (IJAS), 3(17), 78-96.

Taylor, S., Bogdan, R., \& DeVault, M. L. (1998). Introduction to qualitative research methods: A guidebook and resource. Third edition. John Wiley \& Sons.

Torquati, J., Cutler, K., Gilkerson, D., \& Sarver, S. (2013). Early childhood educators' perceptions of nature, science, and environmental education. Early Education \& Development, 24(5), 721-743. https://doi.org/10.1080/10409289.2012.725383

Y1ldirım, B., \& Altun, Y. (2015). Investigating the effect of STEM education and engineering applications on science laboratory lectures. El-Cezeri Journal of Science and Engineering, 2(2), 28-40.

Yücelyiğit, S., \& Toker, Z. (2021). A meta-analysis on STEM studies in early childhood education. Turkish Journal of Education, 10(1), 23-36. https://doi.org/10.19128/turje.783724 


\section{TÜRKÇE GENIŞLETILMIŞ ÖZET}

21. yüzyıl dünyasında bireylerden fen, teknoloji, mühendislik ve matematik alanlarında bilgi ve beceriye sahip olma beklentileri artmaktadır. 21. yüzyıl vatandaşları enerji, doğal kaynaklar, salgınlar vb. gibi karmaşık, çok disiplinli ve dinamik problemlerle karşı karşıya kalmaktadır. K-12 düzeyinde STEM eğitimi bu anlamda öğrencilere, bilim, teknoloji, mühendislik disiplinlerinin gerektirdiği bir dizi bilişsel süreç becerisini deneyimleyebilmeleri için olanak sağlar. Başka bir deyişle, "STEM eğitimi, birden fazla STEM konu alanının kesiştiği noktada işbirliği içinde oluşturulan bilgi, beceri ve inançları içerir" (Corlu, 2017; Corlu vd., 2014).

Karmaşı problem çözme ve bilimsel sorgulama becerilerine sahip bireylere duyulan ihtiyaca dayalı olarak eğitim politikası belgelerinde STEM eğitiminin önemi vurgulanmıştır. STEM eğitimi, yenilikçi eğitim programlarına rehberlik etme (Bybee, 2013) ve yenilikçi zihniyet yapısına sahip nesiller yetiştirme (Corlu, 2012) potansiyeli ile çağdaş eğitim çıktılarıyla uyumludur. Politika belgelerinde STEM eğitiminin odak noktası, öğretmenlerin anlamlı öğrenmeye odaklanan öğrenme ortamları oluşturmasını kolaylaştıran öğrenci merkezli bir yaklaşımı içerir (Ulusal Araştırma Konseyi [NRC], 2011). Milli Eğitim Bakanlığı (MEB) tarafından yayınlanan eğitim vizyon belgesi de STEM eğitimi kapsamında kaliteli öğrenme deneyimlerinin sağlanması gereğini vurgulamaktadır (MEB, 2019).

STEM eğitimi konusunda ortak bir pedagojik anlayış oluşturmak ve uygulamaya dönüştürmek için öğretmen yetiştirme programlarının içeriği ve niteliği konusu gündeme gelmektedir. Araştırmalar, bütünleştirilmiş öğretim programlarından mezun olan öğretmenlerin, disiplin merkezli programlardan mezun olan meslektaşlarına göre daha özgüvenli ve daha olumlu tutumlara sahip olduklarını göstermektedir (Corlu, 2012). Dengeli bir içeriğe sahip bir programda yer alan pedagoji ve pedagojik alan bilgisi dersleri sayesinde, öğretmen adayları bütünleşik öğretmenlik bilgilerini ve paralel öğretim uygulamalarını geliştirmek için daha fazla firsat bulmaktadırlar (Corlu, 2012; Sanders, 2009). Bütünleşik öğretmenlik bilgisi, öğretmenleri sadece kendi konularını öğretmekten değil, aynı zamanda öğrencilerine en az bir diğer STEM disiplini konusunda rehberlik etmekten de sorumlu kılar (Sanders, 2009). Bütünleşik öğretmenlik bilgisine sahip öğretmenler, STEM disiplinleri arasındaki bağlantılarla birlikte gerçek yaşamla güçlü bir ilişkiye dayalı çalışmalar gerçekleştirebilmektedir. Geleceğin öğretmenlerini STEM konularını bütünleşik bir yaklaşımla öğretmeye hazırlamak için öğretmen eğitim programlarının yeniden düzenlenmesinin, 21. yüzyılda toplumsal refahın sağlanması için önemli olduğu düşünülmektedir (Corlu, 2012).

Bütünleşik öğretmenlik bilgisinin önemi çerçevesinde, Türkiye'deki yüksek öğretim politikası da öğretmen yetiştirme programlarına bütünleşik öğretmenlik bilgi ve becerileri için yeni dersler eklenmesine olanak sağlamaktadır. Önceki y1llarda uygulanan standart öğretmen eğitimi programlarından sonra, 2020 yılında Yüksek Öğretim Kurulu, üniversitelere kendi öğretmen eğitimi programlarını oluşturabilmeleri konusunda yetki vermiştir. Bu nedenle, öğretmen adaylarının STEM disiplinleri arasındaki doğal ve aktif bilgi, beceri ve inanç etkileşimlerini sınıf ortamlarında kullanabilmelerine yardımcı olacak bütünleşik öğretmenlik bilgilerinin gelişimi için araştırmaya dayalı ders modellerinin (Corlu, 2012) geliştirilmesi önemli görülmektedir.

Yukarıda açıklanan gerekçelerden hareketle, mevcut araştırmanın amacı STEM: Bütünleşik Öğretmenlik Çerçevesi kapsamında uygulanan "Genç STEM Araştırmacıları ve Uygulayıcıları" Programının etkisinin incelenmesi olarak belirlenmiştir. STEM eğitimi konusunda deneyimli öğretmen eğitimcileri ve öğretmenler tarafından yürütülen program kapsamında, eğitim fakültesi son sınıf öğrencileri STEM eğitimi ile ilgili araştırma ve uygulama faaliyetlerinde bulunmaktadırlar. Programın amac1, STEM bütünleşik öğretmenlik bilgi ve becerilerini öğretmen yetiştirme sürecine dahil etmektir. Bu kapsamda, Genç STEM Araştırmacıları ve Uygulayıcıları Programının etkisi katılımcıların program deneyimleri ve STEM algıları üzerinden incelenmiştir. Çalışmanın bulguları 1şığında, öğretmenlerin STEM bütünleşik öğretmenlik bilgi ve becerilerini geliştirmek amaciyla öğretmen yetiştirme 
programlarının içeriğine katkıda bulunabilecek çıkarımlara ulaşılabileceği düşünülmektedir. Çalışmanın amacı doğrultusunda aşağıdaki araştırma sorularına yanıt aranmıştır:

1. “Genç STEM Araştırmacıları ve Uygulayıcıları" programı katılımcılarının, program bileşenleri ve bu bileşenlerin kişisel ve mesleki gelişimlerine etkisi hakkında deneyimleri nelerdir?

2. "Genç STEM Araştırmacıları ve Uygulayıcıları" programı katılımcıları farklı STEM eğitimi modellerini nasıl siralamakta ve yorumlamaktadırlar?

Nitel araştırma yöntemlerinden fenomenolojinin kullanıldığı araştırmada, çalışma grubunu Genç STEM Araştırmacıları ve Uygulamacıları programına katılan beş okul öncesi öğretmeni oluşturmuştur. Öğretmenler programa 2016-2017 ve 2017-2018 akademik y1llarında üniversite eğitimlerini sürdürürken katılmışlardır. Katılımcıların program deneyimleri ve STEM algıları hakkında veri toplamak için yüz yüze yarı yapılandırılmış bir odak grup görüşmesi yapılmıştır. Görüşme protokolünde iki grup soru yer almıştır: (1) Programın bileşenleri ve etkisi hakkında sorular, (2) Katılımcıların STEM algıları hakkında sorular. Birinci grup, katılımcıların programla ilgili deneyimleri ve bu deneyimlerin kişisel ve/veya mesleki gelişimlerine etkisi hakkında konuşmalarına rehberlik edecek sorulardan oluşmuştur. İkinci grup sorularda ise katılımcılardan STEM eğitimini tanımlamaları ve verilen STEM eğitim modellerini tercih sırasına göre sıraya koymaları istenmiștir. Sıralamaları için katılımcılara STEM eğitim modelleri (Dare vd., 2019) gösterilmiştir. Verilerin çözümlenmesinde kodları ve kategorileri oluşturmak için önceden belirlenmiş ve yeni ortaya çıkan kodlar birlikte kullanılmıştır. Katılımcıların STEM Eğitim modellerine ilişkin sıralamaları için ise daha çok ve daha az tercih edilen modelleri göstermek üzere bir frekans tablosu hazırlanmış ve her modelin en fazla tercih edildiği sıra temel alınarak ortak bir STEM eğitimi modeli sıralaması oluşturulmuştur.

Birinci araştırma sorusuna yönelik edinilen bulgular katılımcıların programın etkilerini STEM eğitimi hakkında farkındalık ve bütünleşik öğretmenlik bilgilerindeki gelişim kategorileri altında değerlendirdiklerini işaret etmiştir. STEM eğitimi hakkında farkındalık kategorisinde katılımcılar, mesleki gelişime yönelik ihtiyaçlarından, STEM eğitiminin sınıf ortamlarında uygulanması için gereken değişimden ve matematik ile fen alanlarına yönelik kendi tutumlarındaki değişimlerden söz etmişlerdir. Bütünleşik öğretmenlik bilgisi için ise alan bilgisinin yanı sıra, STEM: Bütünleşik Öğretmenlik Çerçevesi 1şı̆̆ında pedagojik alan bilgilerinin de geliştiğini dile getirmişlerdir. Katılımcıların ön plana çıkardıkları program bileşenleri; destekleyici koşullar, işbirlikli öğrenme ve program bileşenleri için öneriler olmuştur. İkinci araştırma sorusu kapsamında STEM algılarına bakıldığında ise katılımcıların STEM disiplinlerini birbirinden ayrık gösteren modelleri en az tercih ettiği görülmüştür. En çok tercih edilen modeller ise gerçek yaşam problemlerinin, mühendisliğin ve mühendislik tasarım sürecinin STEM disiplinlerinin bütünleştirilmesinde bağlam olarak kullanıldığı modeller olmuştur. Araştırmanın bulguları katılımcıların programdan mesleki gelişim ve STEM algısı bakımından yararlandıklarına işaret etmektedir.

İlerleyen araştırmalar için farklı öğretmen yetiştirme programlarına STEM eğitiminin entegre edilmesi konusunda farklı modeller incelenerek, öğretmen adaylarının bütünleşik öğretmenlik bilgilerinin nasıl geliştiğine yönelik çalışmalar yapılabileceği düşünülmektedir. 